\title{
Gapu-Monak Saltwater: Journey to Sea Country Exhibition Site Visit to the Australian National Maritime Museum
}

\author{
Annidette Puni \\ University of Technology Sydney, Faculty of Arts and Social Sciences, PO Box 123, Ultimo NSW \\ 2017, Australia. annidette.puni@student.uts.edu.au
}

DOI: https://doi.org/10.5130/nesais.v4i1.1535

Community. One of the key words that resonated with me during my site visit to the Australian National Maritime Museum for the Gapu-Monuk Saltwater: Journey to Sea Country Exhibition.

As I walked towards the entrance of the building, the image of Djambawa Marawili Am, renowned Indigenous artist and elder, immediately caught my attention. A quote above his image read:

It is time for non-Aboriginal people to learn about this land, learn about the waters. So if we are living the way of reconciliation, you must learn about Native Title and Sea Right.

It was my time to be educated and informed, and the right time was now.

Our small group was greeted by the exhibition guide Beau James, an Indigenous person himself, who acknowledged country in our presence to begin our tour. He explained the reason as to why he was able to acknowledge, but not welcome us to country, as he was not from the region. I felt blessed to witness and be a part of a ceremonial acknowledgement.

On a personal note, I chose not to take photographs of the exhibition out of respect for the community and had recalled from a previous subject the importance of cultural protocols, therefore opting to rely on my photographic memory instead. I did, however, take a photo of the sail structure outside the museum, which harbours both the Aboriginal and Australian flags, and have used it as an illustration to accompany my site visit.

The exhibition showcased forty bark paintings by Yolnu artists from northwest Arnhem Land, exploring the significance of the relationship between Indigenous communities and the sea, with reference to the historical event of the Blue Mud Bay Legal case. Upon entry, our guide Beau James discussed the respect for elders and the naming protocols in relation to those who have passed. Sadly, there was an artist who had passed the previous week and certain cultural and naming protocols (which vary from community and place) were in order as to what the artist's family's wishes were, as to whether their photo and their work were to be removed. He further discussed the importance of 
consulting with Community for such matters, and I was reminded that we as non-Indigenous people should always be respectful and aware of these cultural protocols.

The Mokuy (Spirit figures) carvings, comprised of 36 wooden figures, was my favourite piece, created by a Yolnu artist whom I cannot name as they have sadly passed. Each figure had its own intrinsic markings and varied in height. I asked Beau James whether he knew if the figures were gender-based, to which he replied that he didn't know and that only the artist would. I was fascinated by each figure and wondered about who they once were and their stories. I felt at a loss that I wasn't able to meet this talented artist and ask them this very question and more.

Throughout the exhibition there were dark blue and greyish flags situated in particular spaces with words printed on them in the Community's language. It was mentioned that Community never wrote with letters or capitals and that the design was presented in lower case as to evoke harmony and peace. This further extended my perceptions of the power of language, and how different cultures and dialects have their own understanding of the use of grammar for cultural reasons.

Markings originally painted onto their bodies (which were put onto bark) represented who was related to whom, which made me reflect on the Polynesian culture and in particular the Samoan tattoo called the malu, which is for females and is tattooed from below the knee extending to the upper thigh. These markings are representative of that particular female's family and thus reminded me of the artwork showcased. Beau James also expressed that every piece has a meaning, every piece of bark is used, and every piece tells a story of Indigenous history and culture.

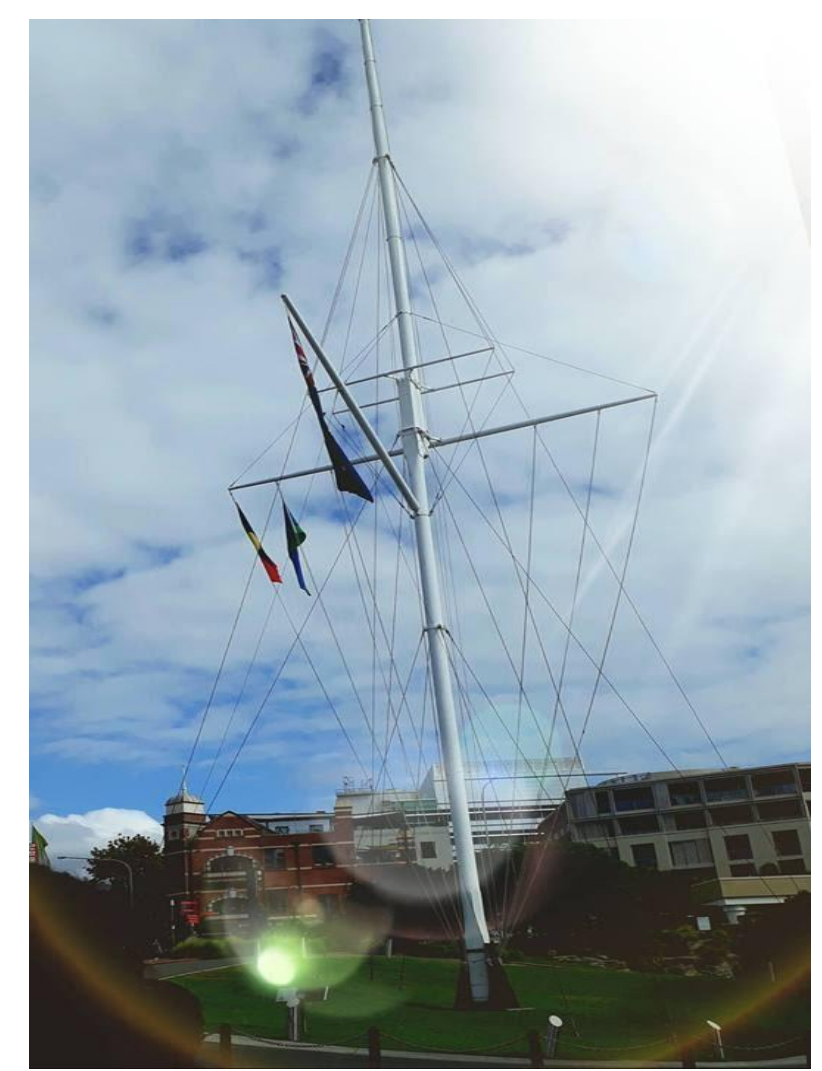

Caption: I chose not to take photographs of the exhibition out of respect for the Community, and have instead used this image taken of the sail structure outside the museum which harbours both the Aboriginal and Australian flags as an illustration to accompany my site visit. 


\section{References}

Australian National Maritime Museum, 2018, Gapu-Monuk Saltwater: Journey to Sea Country, $12^{\text {th }}$ May 2018, <http://www.anmm.gov.au/saltwater>.

Queensland Government: Department of Aboriginal and Torres Strait Islander Partnerships: Protocols for consultation website, accessed $13^{\text {th }}$ May $2018<$ https://www.datsip.qld.gov.au/peoplecommunities/protocols-consultation>.

(c) (1) 2018 by the author(s). This article is distributed under the terms and conditions of the Creative Commons Attribution license (http://creativecommons.org/licenses/by-nd/4.0/). 